\title{
Wildfire and the Future of Water Supply
}

\author{
Kevin D. Bladon, ${ }^{*}, \dagger$ Monica B. Emelko, ${ }^{\S}$ Uldis Silins, $^{\dagger}$ and Micheal Stone ${ }^{\|}$ \\ ${ }^{\dagger}$ Department of Renewable Resources, University of Alberta, Edmonton, Alberta T6G 2H1, Canada \\ ${ }^{\ddagger}$ Department of Forest Engineering, Resources, and Management, Oregon State University, Corvallis, Oregon 97331, United States \\ ${ }^{\S}$ Department of Civil and Environmental Engineering, University of Waterloo, Waterloo, ON N2L 3G1, Canada \\ "Department of Geography and Environmental Management, University of Waterloo, Waterloo, ON N2L 3G1, Canada
}

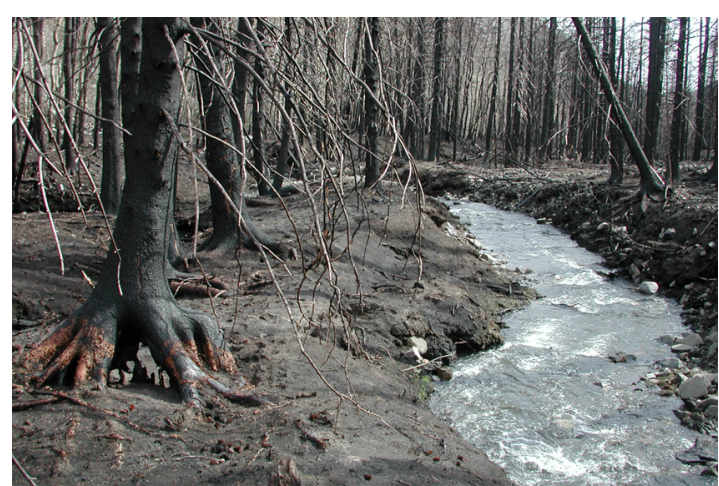

In many parts of the world, forests provide high quality water for domestic, agricultural, industrial, and ecological needs, with water supplies in those regions inextricably linked to forest health. Wildfires have the potential to have devastating effects on aquatic ecosystems and community drinking water supply through impacts on water quantity and quality. In recent decades, a combination of fuel load accumulation, climate change, extensive droughts, and increased human presence in forests have resulted in increases in area burned and wildfire severity-a trend predicted to continue. Thus, the implications of wildfire for many downstream water uses are increasingly concerning, particularly the provision of safe drinking water, which may require additional treatment infrastructure and increased operations and maintenance costs in communities downstream of impacted landscapes. A better understanding of the effects of wildfire on water is needed to develop effective adaptation and mitigation strategies to protect globally critical water supplies originating in forested environments.

T $\mathrm{n}$ many parts of the world, forests provide high quality water for domestic, agricultural, industrial, and ecological needs water supplies in those regions are inextricably linked to forest health. As population and related pressures on already stressed watersheds increase, awareness regarding the effects of largescale landscape change on the water cycle grows increasingly important for the protection of aquatic ecosystem health, and the sustainability of downstream water supplies. The challenge of balancing competing demands is amplified by significant changes in water quality, quantity, timing, and availability that may result from human activities, as well as climate change and related land disturbances (e.g., wildfire, insect pests) in forested regions. ${ }^{1}$ As a result, there has been a paradigm shift in forest management in many regions of the world toward a greater emphasis on preserving clean and abundant water flows from forests. $^{2}$
The high quality and substantial quantity of water flowing from most forests makes these resources particularly vulnerable to impacts of natural and man-made land disturbances. Many of the effects of urbanization, agriculture, and forestry on water quality and quantity, and the associated linkages to both human and aquatic ecosystem health, are well documented. The impacts of land disturbances, such as wildfires, are less understood. Although wildfires can be important in maintaining complex and productive aquatic ecosystems, ${ }^{3}$ severe wildfires have the potential to be devastating to aquatic ecosystems because they may release significant amounts of sediment, ${ }^{4}$ nutrients, ${ }^{5}$ heavy metals, ${ }^{6}$ and other contaminants. ${ }^{7}$ These impacts may recover within a few years or last for numerous decades and extend far beyond the forested headwaters. ${ }^{8,9}$ In recent decades, many regions of the world have experienced changes in seasonal weather that have resulted in earlier and longer fire seasons. ${ }^{10,11}$ These trends are largely attributable to climate change and are likely to continue. ${ }^{12}$ Thus, the implications of wildfire for many downstream water uses are increasingly concerning, particularly the provision of safe drinking water, which may require additional treatment infrastructure and increased operations and maintenance costs in communities downstream of impacted landscapes. ${ }^{13}$ A better understanding of the effects of wildfire on water is needed to develop effective adaptation and mitigation strategies to protect globally critical water supplies originating in forested environments.

\section{FORESTS: CRITICAL SOURCES OF WATER SUPPLY}

Forests cover approximately 31\% (4 billion hectares) of the total global land mass, providing a broad range of economic and ecological goods and services that include natural storage, filtration, and provision of drinking water supplies. Most healthy forests produce high quality water because they grow in regions with high annual precipitation and produce large quantities of runoff with relatively low contaminant concentrations. High quality water from forested source watersheds can have substantial economic benefits by limiting costs for extensive drinking water treatment and associated infrastructure. It has been estimated that the value of the natural storage and filtration of water provided by global forests is approximately $\$ 4.1$-trillion US (2013) per year. ${ }^{14}$ Not surprisingly, many population centers rely heavily on the water provided by forests. For example, almost two-thirds of the municipalities in the United States and about one-third of the world's largest cities, including Tokyo, Melbourne, Los

Published: July 9, 2014 
Angeles, and Rio de Janeiro, receive the majority of their drinking water from forested areas. ${ }^{15}$ Recent water supply shortages, such as the 2011 and 2012 droughts across the U.S. midwest, have renewed public, professional, and government interest in understanding the critical importance of forests in regulating water quantity and quality. ${ }^{16}$

\section{A NEW ERA OF MEGA-FIRES: UNPRECEDENTED WILDFIRE SIZE AND SEVERITY}

Historically, wildfire has been an integral, natural element of healthy terrestrial and aquatic ecosystems because it significantly governs the structure and function of plant and animal communities and biogeochemical cycling. Globally, wildfires burn extensive areas every year ( 300-450 Mha)..$^{17}$ Over the period of record (1960-2013) an average of 1.8-million ha year $^{-1}$ has burned in the U.S. ${ }^{18}$ (Figure 1), while in Canada and

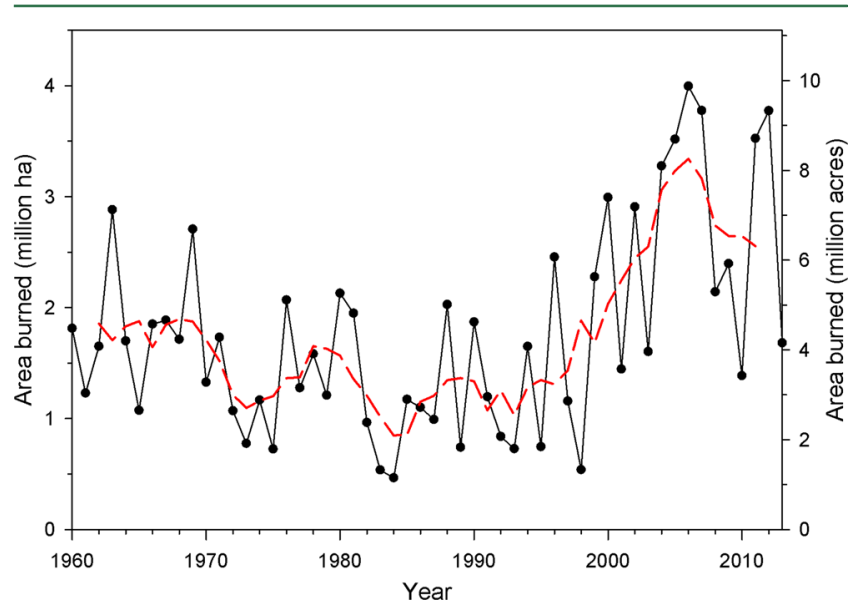

Figure 1. Annual area burned in the U.S. from 1960 to 2013. The red dashed line indicates the rolling 5 -year average area burned. ${ }^{18}$

Australia approximately 2.1-million and 0.8-million ha year ${ }^{-1}$, respectively, burned during a similar period. ${ }^{19}$ Paleoecological records and landscape-scale data have shown that fire frequency has continually responded to climate change, with periods of intense drought featuring more fires and higher severity fires. $^{20,21}$ The Intergovernmental Panel on Climate Change (IPCC) noted that climate warming will continue to increase the risk of more extreme fire events. ${ }^{12}$ This is consistent with predictions of more frequent, larger fires in Canada, the western U.S., South America, central Asia, southern Europe, southern Africa, and Australia. ${ }^{10,22}$ While climate is generally the dominant driver defining fire's domain, a desire to protect a range of economic, recreational, and ecological forest values has led to decades of intensive fire suppression, contributing to decreases or exclusion of wildfire from the landscape in many regions (Figure 1). The accumulation of forest fire fuels (Figure 2) has been an unintended consequence of aggressive fire suppression policies, creating conditions in some areas in which extreme wildfire behavior over a greater area may be more likely. Thus, in recent decades, a combination of climate change, extensive droughts, fuel load accumulation, and increased human presence in forests (wildland-urban interface) have contributed to an increasing trend in wildfires in many parts of the world (Figure 1), resulting in increases in area burned despite increasingly sophisticated advancements in fire suppression technologies and billions of dollars spent on fire management and fire suppression annually. ${ }^{23-25}$ This new wildfire regime includes "mega-fires", a new class of rare wildfires with behavior that exceeds all efforts at control, regardless of the type, size, or number of fire suppression resources deployed. ${ }^{26}$

Mega-fires have increased alarmingly in many parts of the world. In North America and Australia, mega-fires now account for approximately $90-95 \%$ of the annual area burned, even though they represent $<1 \%$ of the number of wildfires. ${ }^{27}$ These fires can cause catastrophic damages that include human casualties and substantial economic losses. The 2009 Black Saturday mega-fire, for example, represents the deadliest natural disaster in Australia's history, burning approximately half a million hectares, killing 173 people, and destroying more than 5500 homes and structures. ${ }^{28}$ The second costliest disaster in Canada was the 2011 Slave Lake mega-fire ( \$700-million in damages). ${ }^{29}$ Recent mega-fires in Greece, the Russian Federation, South Africa, southeast Asia, and Latin America have also been some of the most catastrophic in those countries/continents history, collectively burning >30-million hectares of forested land. ${ }^{30}$

Projections for increased occurrence of catastrophic megafires have intensified concerns regarding the threats posed to the high quality water from forested landscapes and resulted in many new initiatives to reduce wildfire threats to aquatic systems and drinking water supply. The U.S. Department of Agriculture (USDA) Forest Service announced a new vision for America's forests in 2009 with a focus on promoting disturbance-resistant and resilient forests to ensure that forested landscapes continue to provide clean, abundant water supplies. ${ }^{2}$ The USDA has already committed nearly \$22-million to Collaborative Forest Landscape Restoration projects designed to maintain and improve water quality from forested water-

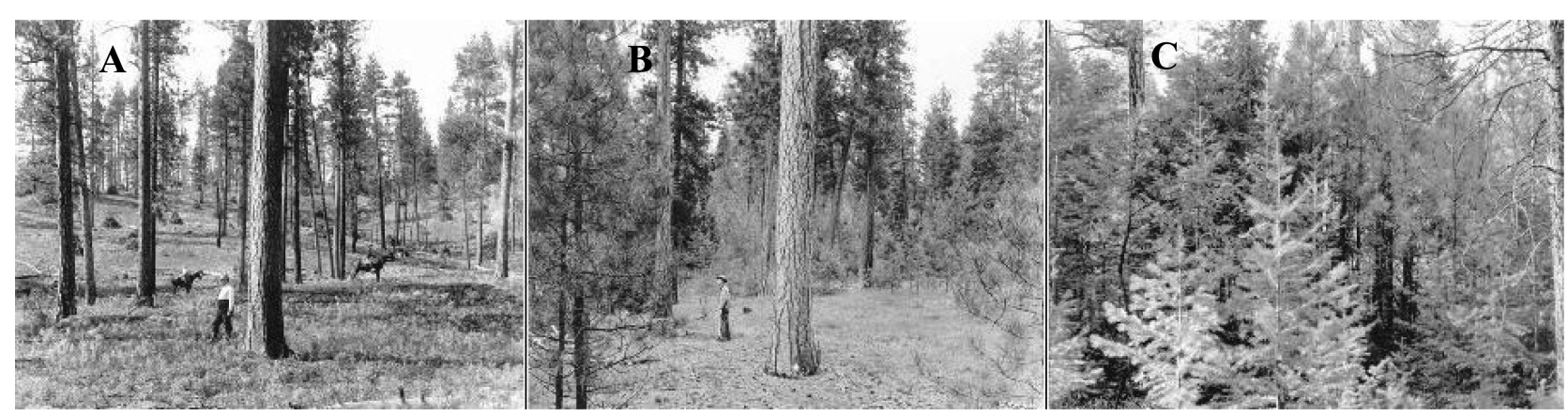

Figure 2. Changes in vertical arrangement and horizontal continuity in a ponderosa pine stand in Bitterroot National Forest, Montana over time (A, 1909; B, 1948; C, 1989) in which fire was excluded since 1895. (Source: US Forest Service.) ${ }^{77}$ 
sheds across the U.S. primarily by reducing wildfire risk. It also launched Forests to Faucets, aimed at modeling and mapping land areas of the continental U.S. most important to surface drinking water, the role forests play in protecting these areas, and the extent to which these forests are threatened by wildfire. Despite these positive actions, even the most aggressive fire suppression and land and fuels management programs are not likely to prevent mega-fires.

\section{MORE WATER, MORE OFTEN?}

Wildfires can affect hydrological processes (interception, infiltration, and evapotranspiration) that influence the timing and magnitude of streamflows (base flows, peak flows, and annual water production). ${ }^{31}$ Consumption of forest vegetation by fire reduces evaporative losses from forests through precipitation interception and evapotranspiration, thereby increasing rain and snow reaching the ground and increasing soil moisture, runoff, and streamflows. ${ }^{32}$ Furthermore, in temperate climates greater solar energy reaching the snowpack also causes earlier onset of snowmelt, which may have significant implications for reservoir storage and aquatic ecosystem health. In the Northern Rocky Mountains, for example, unburned forested sites captured $55-60 \%$ of the snow water equivalent (SWE) compared to burned sites and complete removal of the snowpack occurred approximately 9-15 days earlier in burned stands because of a 2 -fold increase in snowmelt rates. ${ }^{33}$

Postfire hydrological processes can also be impacted by high temperatures that may damage soils in ways that are complex and not well understood. In some instances, a water repellent (hydrophobic) layer develops at or near the soil surface, while in other cases a natural background water repellent layer is exposed after burning and removal of the protective vegetation and litter and duff. ${ }^{34}$ This can severely reduce or prevent water from wetting or infiltrating into soils during rain storms or snowmelt, promoting rapid overland runoff. ${ }^{35}$ The degree of fire-induced water repellency and its longevity after wildfire tend to be most pronounced in coarse grained soils, drier soils, and after higher intensity and severity fires. ${ }^{36}$ High severity fires can also produce complex responses in aggregate stability of soils ranging from disaggregation to strong aggregation depending on soil characteristics (e.g., texture, water content, organic matter). ${ }^{37}$ These changes in soil characteristics can affect hydrologic properties, such as infiltration, which promote greater overland flow and more rapid delivery of water to streams. ${ }^{38}$ The timing and amount of runoff from a site may also be influenced by surface sealing due to postfire ash layer, fine sediments, and needle cast. ${ }^{39}$ Collectively, the impacts of wildfire on hydrologic processes can cause precipitation with frequent return intervals to generate disproportionately large peak flows, shorten time to peak flows, and increase susceptibility to flash floods. ${ }^{40}$

Long-term records of prefire streamflows (discharge) are rarely available, making it difficult to evaluate the subsequent effects of fire. However, in the few cases where data are available, 2- to 5-times increases in peak flows over 6-7 years have been reported. ${ }^{40}$ More typically, unit-area peak flows after wildfires are compared to nearby unburned, reference catchments; however, these data are not ideally comparative because of inherent differences in watershed behavior that reflect the unique interaction of vegetation, topography, geology, drainage form, and climate that govern hydrologic response. Several investigations have concluded that lower severity wildfires produce small or no measurable effects on postfire peak flows while the combination of moderate to high severity burns and short-intense precipitation events can produce peak flows that are 5- to 870-times larger than those previously observed in unburned catchments. ${ }^{32,41}$

\section{EROSION: PASSING ON THE LEGACY OF WILDFIRE TO WATER}

Soil erosion is a leading cause of global water pollution: it involves the detachment, breakdown, transport/redistribution, and deposition of sediments. Wildfires increase the susceptibility of soils to erosion, which depends on multiple factors, including fire severity, site specific characteristics (e.g., watershed area, topography, geology, vegetation, sediment availability), and variability in precipitation and snowmelt. ${ }^{42}$ Compared to lower severity fires, higher severity fires consume a greater proportion of aboveground vegetation, forest litter, and other organic matter (e.g., roots) within the soil - these impacts expose more of the soil to precipitation and, in some cases, increase erosion by several orders of magnitude. ${ }^{5,31}$ The greatest erosion events typically occur before vegetation has redeveloped and often coincide with episodic, short-duration, high intensity rain storms immediately following severe wildfire. $^{40}$ Accelerated erosion, coupled with the occurrence of hydrophobic soils, reduced water infiltration rates, overland runoff, or mass soil failures on hillslopes can also produce catastrophic debris flows in some environments. ${ }^{43}$

The redistribution and delivery of mineral soil and ash from hillslopes to receiving streams after wildfire can have devastating consequences on water quality. Increased sediment loading can elevate turbidity and act as a vector for downstream transport of contaminants, including heavy metals, nutrients, organics, and pathogens. ${ }^{44}$ These impacts may propagate downstream and manifest in reservoirs and lakes because fine sediment has lower postfire settling velocities due to higher organic content and porosity. ${ }^{45}$ Postfire sediment loads and turbidity are generally much higher and more variable than in undisturbed streams, especially following severe fires and after storm flows or during spring snowmelt. ${ }^{9,13}$ The high severity Hayman fire (Colorado), for instance, caused turbidity to increase 3- to 4-fold because of high erosion rates compared to watersheds burned at a lower severity. ${ }^{46}$

Aquatic ecosystems can be impacted (growth and survival of macrophytes, aquatic invertebrates, and fish) by sediment and turbidity through clogging of the streambed with fine sediment, increased channel instability, altered stream temperatures, impairment of fish feeding, and destabilized channel morphology. ${ }^{47,48}$ Shifts in macroinvertebrate communities in Idaho streams, for example, were attributed to increased sediment following a high severity wildfire. ${ }^{49}$ Similarly, in Australia, fish abundance decreased by as much as $95-100 \%$ in burned stream reaches due to increased postfire sedimentation and subsequent decreased dissolved oxygen levels. ${ }^{50}$

From a water supply perspective, postfire sediment loads increase the probability of degrading water quality (taste, odor, color), impairing drinking-water treatment processes and decreasing the operational life-span of reservoirs. ${ }^{13}$ For instance, vast quantities of sediment $\left(\sim 765,000 \mathrm{~m}^{3}\right)$, ash, and debris flowed into the City of Denver's water supply reservoirs (Cheesman and Strontia Springs) after the 2002 Hayman fire, which burned $\sim 55,850$ ha of forest in the Colorado Rockies. ${ }^{51}$ To minimize the impacts, Denver Water invested \$7.3-million on several restoration strategies after the fire and also planted 

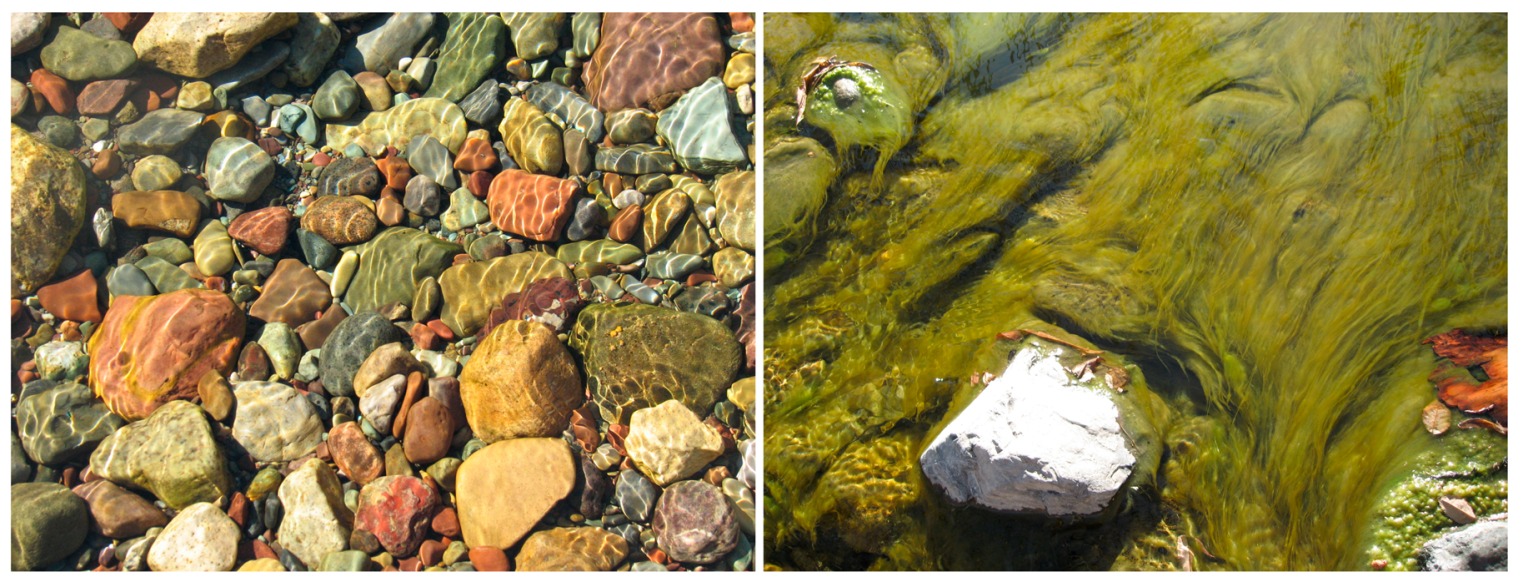

Figure 3. Examples of unburned (left) and postfire (right) stream beds. (Source: Southern Rockies Watershed Project.) ${ }^{8}$

175,000 trees over seven years after the fire. Despite these efforts, a \$30-million dredging project was required in 2010 to remove $\sim 480,000 \mathrm{~m}^{3}$ of sediment from the Strontia Springs Reservoir-enough to cover a football field to a depth of 61 m. ${ }^{52}$ In 2012, severe wildfires (Waldo Canyon, Hewlett Gulch, and High Park) burned forests throughout Colorado, necessitating the installation of upstream monitors to gauge ash and sediment levels, diversion of sooty water from treatment plant intakes, and restoration efforts to prevent mud, debris, and ash from entering water supplies.

Once in the stream, eroded materials may be transported downstream or deposited and "stored" in stream beds, river banks, and flood plains during periods of low flow. These sediments are often remobilized and transported further downstream during subsequent high flow periods (e.g., summer rain storms, spring snowmelt). ${ }^{4,53}$ Thus, while increased erosion rates generally diminish quickly after fire $(\sim 3-8$ years), the legacy of this impact may be extremely long-lasting $(\sim 10$ to $>100$ years $) .{ }^{9,54}$ Four years after the Buffalo Creek fire in Colorado, for example, it was estimated that $67 \%$ of the sediment mobilized by postfire erosion remained stored in streams and would likely persist for more than 300 years. ${ }^{40}$ As fires become more severe in the future, to the point of deleteriously impacting tree colonization and forest regrowth, erosion rates and associated sediment storage in streams can only be expected to increase. 4,46

\section{VARIABLE HEAVY METAL RELEASES}

Wildfires liberate accumulated heavy metals, possibly in alarmingly high pulses, to the atmosphere and adjacent streams, potentially impacting terrestrial and aquatic ecosystem health. ${ }^{55}$ This is often most pronounced when fires burn mature forests, especially where fire has been suppressed and heavy metals may have accumulated for years or decades because of atmospheric deposition. ${ }^{56}$ The 2002 Hayman fire in the mature forests along the Colorado Front Range of the Rocky Mountains, for example, resulted in 2- to 2500-times increases in the concentrations of arsenic, aluminum, cadmium, iron, lead, and mercury. ${ }^{57}$ Similarly, after the 2003 Lost Creek wildfire, mean concentrations of many metals were elevated in burned watersheds and postfire salvage logged watersheds for at least five years after the fire. ${ }^{58}$ Following the 2010 Fourmile Canyon fire near Boulder, Colorado, in-stream concentrations of aluminum, iron, and manganese also were elevated. ${ }^{59}$
While postfire metal concentration and export data for receiving streams are limited, the strong affinity of metals for ash and fine sediments indicates fire effects on metals may be long lasting. ${ }^{60}$ Because sediment is the primary vector for metal transport, the highest in-stream heavy metal concentrations and exports are typically associated with intense summer storms and spring snowmelt events when erosion rates of burned materials and surface soils are greatest. A postfire rain storm $(\sim 38 \mathrm{~mm}$ in $2 \mathrm{~h}$ ) in southeast Australia, for example, delivered large amounts of sediment $\left(59,000 \mathrm{mg} \mathrm{L}^{-1}\right.$ suspended solids and $129,000 \mathrm{NTU}$ ) into a drinking water supply, causing concentrations of arsenic, iron, lead, and chromium to rise to levels exceeding World Health Organization (WHO) guidelines. ${ }^{61}$ Similarly, during the first two years after the Lost Creek fire, total mercury concentrations exceeded both chronic and acute provincial water quality guidelines on multiple occasions during storm events. An extremely high mercury pulse of 265 $\mu \mathrm{g} \mathrm{L}^{-1}\left(0.001 \mu \mathrm{g} \mathrm{L}^{-1}=\right.$ maximum acceptable concentration in drinking water) was measured after a moderate precipitation event $(\sim 20 \mathrm{~mm})$ several days following a very large event that fully saturated the ground and produced very high stormflow. ${ }^{13}$ Mercury is particularly concerning because of its potential to bioaccumulate and biomagnify, which can result in health problems for consumers of fish. ${ }^{6}$ Forest fires in a range of environments have produced elevated total and methyl mercury concentrations in sediment and fish-in some cases exceeding the advisory limit for human consumption $\left(0.5 \mu \mathrm{g} \mathrm{g}^{-1}\right.$ wet weight) from the World Health Organization (WHO). ${ }^{62}$

\section{NUTRIENT LEGACY OR RECOVERY?}

Aquatic ecosystem structure and composition can be rendered almost unrecognizable (Figure 3) by high intensity, high severity wildfires, which release significant amounts of nutrients that have the potential to contribute to substantive shifts in water quality. Increased occurrence of mega-fires has underscored the need to understand how wildfires, especially in forested headwaters, impact nutrient concentrations or loads, threatening aquatic systems, recreational water use, and municipal water supply (Figure 4$).^{5}$ A variety of materials are released when organic matter (dead and living) undergoes complete or partial combustion and the ash is deposited on the soil surface. Nutrients associated with ash or those remaining on-site are susceptible to leaching into and through soil. Some nutrients (phosphorus, nitrogen, carbon) can be transported in dissolved or particulate forms (associated with ash or sediment) 


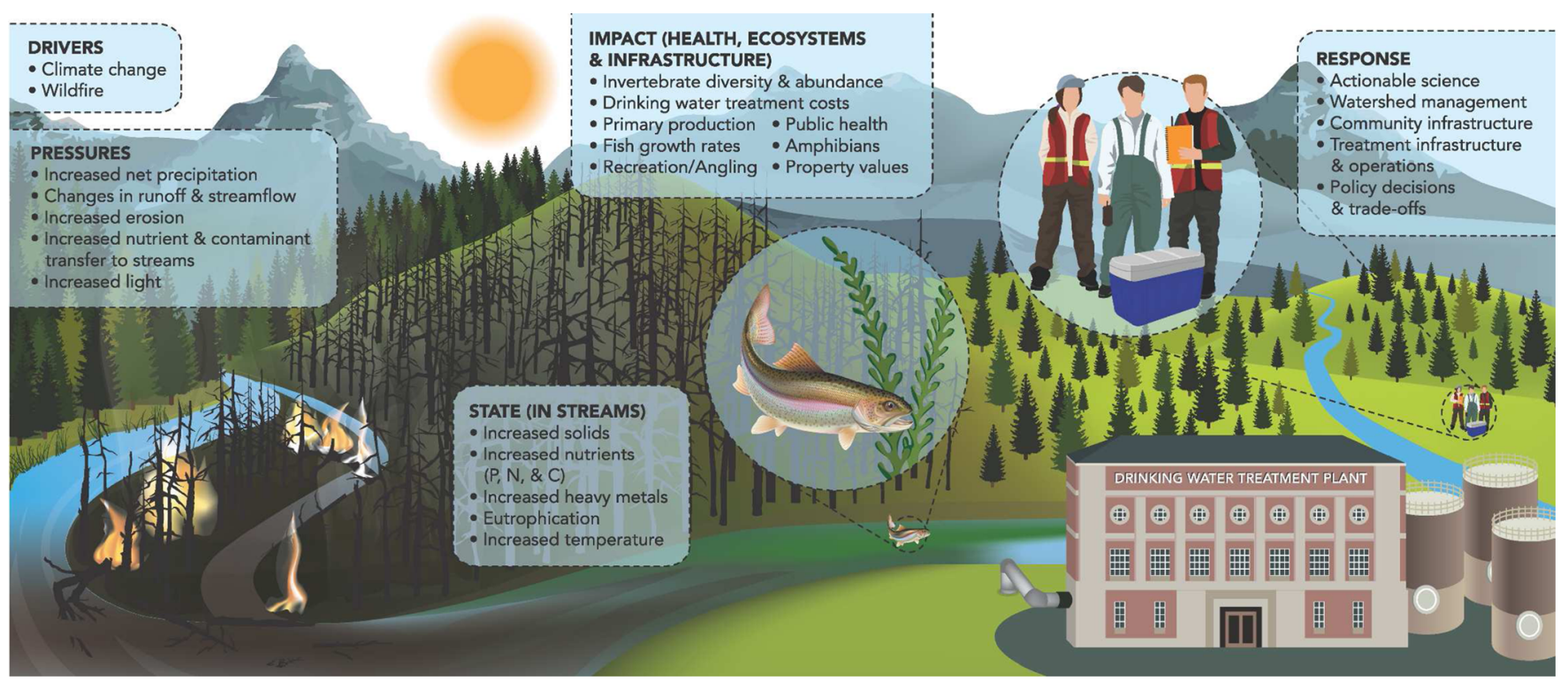

Figure 4. Water supply pressures, state, and impact due to wildfire, including potential responses to mitigate the impacts in the future.

by surface runoff or wind into adjacent streams. ${ }^{63}$ Streams that drain burned forested landscapes often have increased levels of phosphorus, nitrogen, dissolved organic carbon (DOC), sulfate, chloride, calcium, magnesium, sodium, and potassium. ${ }^{5,13}$ However, the magnitudes and duration of water quality changes following fire are highly variable, depending primarily on the interaction between fire characteristics (frequency, intensity, severity), watershed characteristics (physiography, soils, geology, vegetation type), postfire climatic regime, and pollutant of interest. As a result, observations have often been conflicting, even for similar ecosystem types. This makes it difficult to generalize expected water quality and ecosystem responses and to apply knowledge derived from one region to another.

The nutrient shifts of greatest concern after fire are those observed in phosphorus, nitrogen, and carbon, which are the foundational elements of aquatic ecosystems. Small increases in nutrients $\mathrm{P}$ and $\mathrm{N}$, for example, in combination with greater light availability because of reduced shade from the burned riparian canopy can accelerate growth of aquatic plants and benthic communities, which alter aquatic ecosystem structure and composition. ${ }^{8,64}$ Excessive inputs of $\mathrm{P}$ and $\mathrm{N}$ increase the risk of eutrophication of freshwater systems-one of the most widespread water quality issues globally-by reducing water quality, causing toxic algal blooms, and increasing fish kills. ${ }^{65} \mathrm{~A}$ conservative estimate of the current costs of eutrophication of U.S. fresh water is $\$ 813$ million annually: ${ }^{66}$ this value will likely rise in areas impacted by larger, more severe wildfires.

In wildfire-affected streams, the production of $\mathrm{N}$ can range from $\sim 2$ - to 250-times greater than those in undisturbed streams. ${ }^{8}$ The largest fluxes of $\mathrm{N}$ (primarily as nitrate) are generally observed in the first year postfire as $\mathrm{N}$ is rapidly mobilized with runoff. ${ }^{67}$ Thereafter, high $\mathrm{N}$ fluxes typically only coincide with extreme precipitation events. In contrast, wildfire impacts on P production can exceed those of other nutrients. In burned watersheds, $\mathrm{P}$ concentrations 1.4- to 400-times greater than those in unburned watersheds have been reported. ${ }^{6,68}$ In contrast to N, P transport in surface runoff from hillslopes to receiving waters is predominantly particle-associated and linked with erosion, which can become an important long-term source of $\mathrm{P}$ for aquatic ecosystems. ${ }^{8,69}$ Sediments in river beds draining burned landscapes can contain a higher fraction of the most bioavailable forms of $\mathrm{P}$, thus these $\mathrm{P}$ rich riverbed sediments can prolong the effects of wildfire on $\mathrm{P}$ concentrations in fire affected rivers. $^{70}$

Much of our current understanding of nutrient $(\mathrm{P}, \mathrm{N}, \mathrm{C})$ mobility and fate after fire originates from studies of low severity fires. Data from catastrophic fires are scarce and the effects are poorly understood. More severe, stand-replacing wildfires could result in greater nutrient availability and delivery to streams. For example, following the Greater Yellowstone Ecosystem fires (1988) in mature lodgepole pine forests, a gradient was observed in stream nitrate and phosphate concentrations with severe burn $>$ moderate burn $>$ light burn $>$ unburned watersheds. ${ }^{71}$ Following fires in the San Dimas Experimental Forest in California, nitrate concentrations in streams corresponded with burn severity; moderate fires produced concentrations 3-times greater than unburned watersheds, while severely burned watersheds produced concentrations $\sim 40$-times greater than unburned watersheds. ${ }^{72}$ Similar to sediment, the longer term legacy of water quality effects may persist following severe wildfires, which can delay vegetation regeneration due to high soil seed-bank mortality or a deep ash layers resulting in poor germination success. ${ }^{73}$

Dissolved organic carbon (DOC) is a critical component of the carbon cycle and energy balance in streams and is a primary food source in aquatic food webs. Elevated DOC levels can acidify freshwaters by forming organic acids and decrease light attenuation in streams, which is critical for autotrophs. In addition, DOC can influence the solubility, transport, and toxicity of trace metals and nutrients. ${ }^{74}$ Excess DOC is also a concern for downstream community water supply and consumer health because it can create taste and odor problems, decrease the effectiveness of the water treatment process, increase the formation of potentially carcinogenic chemical disinfection byproducts, and ultimately increase operating costs in impacted communities. ${ }^{13,75}$ DOC concentration data following high intensity or high severity fires are limited. In the first year after the high severity Hayman fire, DOC concentrations were $\sim 3$-fold higher in the burned stream 
(Fourmile Creek) than the unburned (Pine Creek) and the 95th percentile was $25.1 \mathrm{mg} \mathrm{L}^{-1}{ }^{57}$ Similarly, in the first four years after the Lost Creek wildfire in Alberta the 95th percentile DOC remained low in streams draining unburned watersheds $\left(3.8 \mathrm{mg} \mathrm{L}^{-1}\right)$. In contrast, DOC levels were elevated in streams draining burned $\left(4.6 \mathrm{mg} \mathrm{L}^{-1}\right)$ and postfire salvage-logged (9.9 mg L $\left.{ }^{-1}\right)$ watersheds. ${ }^{13}$ The Mortar Creek fire, which burned 26,000 ha of mixed-conifer Rocky Mountain forest, also resulted in elevated DOC concentrations in burned watersheds with the highest concentrations during high flow events (e.g., stormflows, spring snowmelt freshet). ${ }^{76}$

\section{OUTLOOK}

Wildfire can significantly threaten water-with potentially catastrophic implications for aquatic ecosystems, community infrastructure, water supply and treatment, and even public health. While these threats are generally understood, the specific impacts vary substantially by geographic region. Thus, the impacts on ecosystems and humans are highly variablenot only worldwide, but even within specific ecoregions. Impacts produced by one fire are not the same as those produced by another fire; moreover, not all fires are catastrophic. A major challenge remains to provide actionable science and reliable capacity to predict impacts of wildfire on a range of water values (Figure 4). This is impossible without research at appropriate temporal and spatial scales - that means necessarily capturing the effects produced by short- and long-term variation in hydroclimate.

The future of water supply is changing because of climate and its relationship to wildfire. This will likely impact the provision of water for domestic, agricultural, industrial, and ecological needs in some regions. Natural resource managers and agencies responsible for water or land will increasingly need to anticipate and prepare for these effects. Undoubtedly, difficult decisions will need to be made. For example, should drinking water supply and treatment in smaller communities be regionalized? Should forests be managed to protect water from wildfire? Who should pay for land and water management? These decisions will require the meaningful integration of science, management, and policy.

\section{AUTHOR INFORMATION}

\section{Corresponding Author}

*Phone: (541) 737-4952. Fax: (541) 737-4316. E-mail: kevin. bladon@oregonstate.edu.

\section{Notes}

The authors declare no competing financial interest.

\section{Biographies}

Kevin Bladon is an Assistant Professor of Forest Ecohydrology and Watershed Science at Oregon State University, where he investigates the impacts of natural disturbance and land use on hydrology, water quality, and aquatic ecosystem health at the hillslope, stream reach, and small catchment scale.

Monica Emelko is an Associate Professor of Civil and Environmental Engineering at the University of Waterloo and specializes in climate change and related disturbance impacts on drinking water treatability, natural organic matter and treatability, physicochemical processes for drinking water treatment, pathogen transport in porous media, quantitative microbial risk assessment (QMRA), and source water protection.
Uldis Silins is a Professor of Forest Hydrology at the University of Alberta, with research interests in forest disturbance (wildfire, pine beetle, harvesting) effects on hydrology, water quality, aquatic ecology, atmospheric/vegetative controls on water balance, and evapotranspiration dynamics, and ecohydrology of forest stand dynamics.

Mike Stone is a Professor of Geography and Environmental Management at the University of Waterloo, where his research has focused on sediment-associated nutrient/contaminant transport and regional-scale assessment of land-use effects on water quality.

All four coauthors are members of the Southern Rockies Watershed Project (http://www.srwp.ualberta.ca) and have been collaboratively studying impacts of wildfire and climate-associated pressures on water resources and treatability in south western Canada for over a decade.

\section{REFERENCES}

(1) Vörösmarty, C. J.; McIntyre, P. B.; Gessner, M. O.; Dudgeon, D.; Prusevich, A.; Green, P.; Glidden, S.; Bunn, S. E.; Sullivan, C. A.; Liermann, C. R.; Davies, P. M. Global threats to human water security and river biodiversity. Nature 2010, 467 (7315), 555-561.

(2) United States Department of Agriculture. Agriculture Secretary Vilsack Announces New Direction and Vision for America's Forests; USDA Office of Communications: Washington, D.C., 2009.

(3) Bisson, P. A.; Rieman, B. E.; Luce, C.; Hessburg, P. F.; Lee, D. C.; Kershner, J. L.; Reeves, G. H.; Gresswell, R. E. Fire and aquatic ecosystems of the western USA: Current knowledge and key questions. For. Ecol. Manage. 2003, 178, 213-229.

(4) Silins, U.; Stone, M.; Emelko, M. B.; Bladon, K. D. Sediment production following severe wildfire and post-fire salvage logging in the Rocky Mountain headwaters of the Oldman River Basin, Alberta. Catena 2009, 38 (3), 189-197.

(5) Smith, H. G.; Sheridan, G. J.; Lane, P. N. J.; Nyman, P.; Haydon, $S$. Wildfire effects on water quality in forest catchments: A review with implications for water supply. J. Hydrol. 2011, 396 (1-2), 170-192.

(6) Kelly, E. N.; Schindler, D. W.; Louis, V. L. S.; Donald, D. B.; Vladicka, K. E. Forest fire increases mercury accumulation by fishes via food web restructuring and increased mercury inputs. Proc. Natl. Acad. Sci. U. S. A. 2006, 103 (51), 19380-19385.

(7) Crouch, R. L.; Timmenga, H. J.; Barber, T. R.; Fuchsman, P. C. Post-fire surface water quality: Comparison of fire retardant versus wildfire-related effects. Chemosphere 2006, 62 (6), 874-889.

(8) Silins, U.; Bladon, K. D.; Kelly, E. N.; Esch, E.; Spence, J. R.; Stone, M.; Emelko, M. B.; Boon, S.; Wagner, M. J.; Williams, C. H. S.; Tichkowsky, I. Five-year legacy of wildfire and salvage logging impacts on nutrient runoff and aquatic plant, invertebrate, and fish productivity. Ecohydrology 2014, DOI: 10.1002/eco.1474.

(9) Moody, J. A.; Martin, D. A. Synthesis of sediment yields after wildland fire in different rainfall regimes in the western United States. Int. J. Wildland Fire 2009, 18 (1), 96-115.

(10) Pechony, O.; Shindell, D. T. Driving forces of global wildfires over the past millennium and the forthcoming century. Proc. Natl. Acad. Sci. U. S. A. 2010, 107 (45), 19167-19170.

(11) Westerling, A. L.; Hidalgo, H. G.; Cayan, D. R.; Swetnam, T. W. Warming and earlier spring increase western U.S. forest wildfire activity. Science 2006, 313 (5789), 940-943.

(12) Intergovernmental Panel on Climate Change (IPCC). Climate Change 2013: The Physical Science Basis, Working Group I Contribution to the IPCC Fifth Assessment Report; IPCC: Geneva, Switzerland, 2013.

(13) Emelko, M. B.; Silins, U.; Bladon, K. D.; Stone, M. Implications of land disturbance on drinking water treatability in a changing climate: Demonstrating the need for "source water supply and protection" strategies. Water Res. 2011, 45 (2), 461-472.

(14) Costanza, R.; d'Arge, R.; de Groot, R.; Farberk, S.; Grasso, M.; Hannon, B.; Limburg, K.; Naeem, S.; O’Neill, R. V.; Paruelo, J.; Raskin, R. G.; Suttonkk, P.; van den Belt, M. The value of the world's 
ecosystem services and natural capital. Nature 1997, 387 (6630), 253260.

(15) Committee on Hydrologic Impacts of Forest Management. Hydrologic Effects of a Changing Forest Landscape; The National Academies Press: Washington, D.C., 2008; p 157.

(16) Vose, J. M.; Sun, G.; Ford, C. R.; Bredemeier, M.; Otsuki, K.; Wei, X.; Zhang, Z.; Zhang, L. Forest ecohydrological research in the 21st century: What are the critical needs? Ecohydrology 2011, 4 (2), $146-158$.

(17) van der Werf, G. R.; Randerson, J. T.; Giglio, L.; Collatz, G. J.; Kasibhatla, P. S.; Arellano, A. F. Interannual variability in global biomass burning emissions from 1997 to 2004. Atmos. Chem. Phys. 2006, 6, 3423-3441.

(18) National Interagency Fire Centre. Total wildland fires and acres (1960-2013). http://www.nifc.gov/index.html (accessed October 18, 2013).

(19) Canadian Council of Forest Ministers. National Forestry Database, 2013. http://nfdp.ccfm.org/fires/national_e.php (accessed November 14, 2013)

(20) Krawchuk, M. A.; Moritz, M. A. Constraints on global fire activity vary across a resource gradient. Ecology 2011, 92 (1), 121132 .

(21) Pierce, J. L.; Meyer, G. A.; Jull, A. J. T. Fire-induced erosion and millennial-scale climate change in northern ponderosa pine forests. Nature 2004, 432, 87-90.

(22) Wotton, B. M.; Nock, C. A.; Flannigan, M. D. Forest fire occurrence and climate change in Canada. Int. J. Wildland Fire 2010, 19, 253-271.

(23) Bowman, D. M. J. S.; Balch, J. K.; Artaxo, P.; Bond, W. J.; Carlson, J. M.; Cochrane, M. A.; D’Antonio, C. M.; DeFries, R. S.; Doyle, J. C.; Harrison, S. P.; Johnston, F. H.; Keeley, J. E.; Krawchuk, M. A.; Kull, C. A.; Marston, J. B.; Moritz, M. A.; Prentice, I. C.; Roos, C. I.; Scott, A. C.; Swetnam, T. W.; vanderWerf, G. R.; Pyne, S. J. Fire in the earth system. Science 2009, 324 (5926), 481-484.

(24) Flannigan, M.; Cantin, A. S.; de Groot, W. J.; Wotton, M.; Newbery, A.; Gowman, L. M. Global wildland fire season severity in the 21st century. For. Ecol. Manage. 2013, 294 (S1), 54-61.

(25) Dennison, P. E.; Brewer, S. C.; Arnold, J. D.; Moritz, M. A. Large wildfire trends in the western United States, 1984-2011. Geophys. Res. Lett. 2014, DOI: 10.1002/2014GL059576.

(26) The Brookings Institution. The Mega-Fire Phenomenon: Toward a More Effective Management Model; U.S. National Fire and Aviation Board, The Brookings Institution Centre for Public Policy Education: Washington, D.C., 2005; p 15.

(27) Gelber, D.; Bach, J. The age of mega-fires, 2007. http://www. cbsnews.com/video/watch/?id=3389657n (accessed July 19, 2012).

(28) Teague, B.; Mcleod, R.; Pascoe, S. 2009 Victorian Bushfires Royal Commission Final Report Summary; Parliament of Victoria: Melbourne, VIC, 2010; p 52.

(29) Flat Top Complex Wildfire Review Committee Flat Top Complex Final Report; Department of Environment and Sustainable Resource Development, Government of Alberta: Edmonton, $A B$, 2012; p 83.

(30) Global Fire Monitoring Center. Current and archived significant global fire events and fire season summaries. http://www.fire.unifreiburg.de/ (accessed June 3, 2011).

(31) Shakesby, R. A.; Doerr, S. H. Wildfire as a hydrological and geomorphological agent. Earth-Sci. Rev. 2006, 74 (3-4), 269-307.

(32) Neary, D. G.; Gottfried, G. J.; Ffolliott, P. F. In Post-Wildfire Watershed Flood Responses, 2nd International Wildland Fire Ecology and Fire Management Congress and 5th Symposium on Fire Forest Meteorology, Orlando, FL, November 16-20, 2003; American Meterological Society: Boston, MA, 2003; p 7.

(33) Burles, K.; Boon, S. Snowmelt energy balance in a burned forest plot, Crowsnest Pass, Alberta, Canada. Hydrol. Processes 2011, 25 (19), 3012-3029.

(34) Doerr, S. H.; Woods, S. W.; Martin, D. A.; Casimiro, M. "Natural background" soil water repellency in conifer forests of the north-western USA: Its prediction and relationship to wildfire occurrence. J. Hydrol. 2009, 371 (1-4), 12-21.

(35) Huffman, E. L.; MacDonald, L. H.; Stednick, J. D. Strength and persistence of fire-induced soil hydrophobicity under ponderosa and lodgepole pine, Colorado front range. Hydrol. Processes 2001, 15 (15), 2877-2892.

(36) Shakesby, R. A.; Doerr, S. H.; Walsh, R. P. D. Erosional impacts of soil hydrophobicity: Current problems and future research directions. J. Hydrol. 2001, 231-232 (S1), 178-191.

(37) Mataix-Solera, J.; Cerda, A.; Arcenegui, V.; Jordan, A.; Zavala, L. M. Fire effects on soil aggregation: A review. Earth-Sci. Rev. 2011, 109 (1-2), 44-60.

(38) Ebel, B. A.; Moody, J. A. Rethinking infiltration in wildfireaffected soils. Hydrol. Processes 2013, 27 (10), 1510-1514.

(39) Cerdà, A.; Doerr, S. H. The effect of ash and needle cover on surface runoff and erosion in the immediate post-fire period. Catena 2008, 74 (3), 256-263.

(40) Moody, J. A.; Martin, D. A. Initial hydrologic and geomorphic response following a wildfire in the Colorado Front Range. Earth Surf. Processes Landforms 2001, 26 (10), 1049-1070.

(41) Moody, J. A.; Martin, D. A. Post-fire rainfall intensity-peak discharge relations for three mountainous watersheds in the western USA. Hydrol. Processes 2001, 15 (15), 2981-2993.

(42) Moody, J. A.; Shakesby, R. A.; Robichaud, P. R.; Cannon, S. H.; Martin, D. A. Current research issues related to post-wildfire runoff and erosion processes. Earth-Sci. Rev. 2013, 122, 10-37.

(43) Doerr, S. H.; Shakesby, R. A.; MacDonald, L. H. Soil water repellency: A key factor in post-fire erosion? In Fire Effects on Soils and Restoration Strategies; Cerda, A.; Robichaud, P., Eds.; Science Publishers, Inc.: Enfield, NH, 2009; pp 197-223.

(44) Stone, M.; Droppo, I. G. In-channel surficial fine-grained sediment laminae (Part II): Chemical characteristics and implications for contaminant transport in fluvial systems. Hydrol. Processes 1994, 8 (2), 113-124.

(45) Stone, M.; Emelko, M. B.; Droppo, I. G.; Silins, U. Biostabilization and erodibility of cohesive sediment deposits in wildfire-affected streams. Water Res. 2011, 45 (2), 521-534.

(46) Rhoades, C. C.; Entwistle, D.; Butler, D. The influence of wildfire extent and severity on streamwater chemistry, sediment and temperature following the Hayman Fire, Colorado. Int. J. Wildland Fire 2011, 20 (3), 430-442.

(47) Goode, J. R.; Luce, C. H.; Buffington, J. M. Enhanced sediment delivery in a changing climate in semi-arid mountain basins: Implications for water resource management and aquatic habitat in the northern Rocky Mountains. Geomorphology 2012, 139, 1-15.

(48) Wagner, M. J.; Bladon, K. D.; Silins, U.; Williams, C. H. S.; Martens, A. M.; Boon, S.; MacDonald, R. J.; Stone, M.; Emelko, M. B.; Anderson, A. Catchment-scale stream temperature response to land disturbance by wildfire governed by surface-subsurface energy exchange and atmospheric controls. J. Hydrol. 2014, 517, 328-338.

(49) Arkle, R. S.; Pilliod, D. S.; Strickler, K. Fire, flow and dynamic equilibrium in stream macroinvertebrate communities. Freshwater Biol. 2010, 55 (2), 299-314.

(50) Lyon, J. P.; O'Connor, J. P. Smoke on the water: Can riverine fish populations recover following a catastrophic fire-related sediment slug? Austral Ecol. 2008, 33 (6), 794-806.

(51) Meyer, J. P. Hayman fire still mucking up water. Denver Post November 24, 2006; http://www.denverpost.com/ci 4713914.

(52) Denver Water. 2010 Comprehensive Annual Financial Report; Denver Water: Denver, CO, 2010; p 192.

(53) Kunze, M. D.; Stednick, J. D. Streamflow and suspended sediment yield following the 2000 Bobcat fire, Colorado. Hydrol. Processes 2006, 20 (8), 1661-1681.

(54) Moody, J. A.; Martin, D. A. Forest fire effects on geomorphic processes. In Fire Effects on Soils and Restoration Strategies, Cerda, A., Robichaud, P., Eds.; Science Publishers: Enfield, NH, 2009; pp 41-79.

(55) Witt, E. L.; Kolka, R. K.; Nater, E. A.; Wickman, T. R. Forest fire effects on mercury deposition in the boreal forest. Environ. Sci. Technol. 2009, 43 (6), 1776-1782. 
(56) Woodruff, L. G.; Cannon, W. F. Immediate and long-term fire effects on total mercury in forests soils of northeastern Minnesota. Environ. Sci. Technol. 2010, 44 (14), 5371-5376.

(57) Ranalli, A. J.; Stevens, M. R. Streamwater Quality Data from the 2002 Hayman, Hinman, and Missionary Ridge Wildfires, Colorado, 2003, Data Series 109; U.S. Department of the Interior, U.S. Geological Survey: Denver, CO, 2004; p 5.

(58) Silins, U.; Bladon, K.; Stone, M.; Emelko, M.; Boon, S.; Williams, C.; Wagner, M.; Howery, J. Southern Rockies Watershed Project: Impact of Natural Disturbance by Wildfire on Hydrology, Water Quality, and Aquatic Ecology of Rocky Mountain Watersheds, Phase I Final Report (2004-2008); Alberta Sustainable Resource Development: Edmonton, AB, 2009; p 90.

(59) Writer, J. H.; Murphy, S. F. Wildfire Effects on Source-Water Quality-Lessons from Fourmile Canyon Fire, Colorado, and Implications for Drinking-Water Treatment; U.S. Geological Survey: Boulder, CO, 2012; p 4.

(60) Biswas, A.; Blum, J. D.; Klaue, B.; Keeler, G. J. Release of mercury from Rocky Mountain forest fires. Glob. Biogeochem. Cycles 2007, 21 (1), GB1002.

(61) Leak, M.; Passuello, R.; Tyler, B. I've seen fire. I've seen rain. I've seen muddy waters that I thought would never clear again. WaterWorks 2003, 6, 38-44.

(62) Garcia, E.; Carignan, R. Mercury concentrations in fish from forest harvesting and fire-impacted Canadian boreal lakes compared using stable isotopes of nitrogen. Environ. Toxicol. Chem. 2005, 24 (3), 685-693.

(63) Lane, P. N. J.; Sheridan, G. J.; Noske, P. J.; Sherwin, C. B. Phosphorus and nitrogen exports from SE Australian forests following wildfire. J. Hydrol. 2008, 361 (1-2), 186-198.

(64) Spencer, C. N.; Gabel, K. O.; Hauer, F. R. Wildfire effects on stream food webs and nutrient dynamics in Glacier National Park, USA. For. Ecol. Manage. 2003, 178 (1-2), 141-153.

(65) Schindler, D. W. The dilemma of controlling cultural eutrophication of lakes. Proc. R. Soc. B 2012, 279 (1746), 4322-4333.

(66) Dodds, W. K.; Bouska, W. W.; Eitzmann, J. L.; Pilger, T. J.; Pitts, K. L.; Riley, A. J.; Schloesser, J. T.; Thornbrugh, D. J. Eutrophication of U.S. freshwaters: Analysis of potential economic damages. Environ. Sci. Technol. 2009, 43 (1), 12-19.

(67) Bladon, K. D.; Silins, U.; Wagner, M. J.; Stone, M.; Emelko, M. B.; Mendoza, C. A.; Devito, K. J.; Boon, S. Wildfire impacts on nitrogen concentration and production from headwater streams in southern Alberta's Rocky Mountains. Can. J. For. Res. 2008, 38 (9), 2359-2371.

(68) Schindler, D. W.; Newbury, R. W.; Beaty, K. G.; Prokopowich, J.; Ruszczynski, T.; Dalton, J. A. Effects of a windstorm and forest fire on chemical losses from forested watersheds and on the quality of receiving streams. Can. J. Fish. Aquat. Sci. 1980, 37 (3), 328-334.

(69) Burke, J. M.; Prepas, E. E.; Pinder, S. Runoff and phosphorus export patterns in large forested watersheds on the western Canadian Boreal Plain before and for 4 years after wildfire. J. Environ. Eng. Sci. 2005, 4 (5), 319-325.

(70) Allin, D.; Stone, M.; Silins, U.; Emelko, M. B.; Collins, A. L. In The Effects of Wildfire on Sediment-Associated Phosphorus Forms in the Crowsnest River Basin, Alberta, Canada, Wildfire and Water Quality: Processes, Impacts and Challenges, Banff, AB, June 11-14, 2012; Stone, M., Collins, A., Thoms, M., Eds.; IAHS-ICCE: Rennes, France, 2012; pp 1-8.

(71) Brass, J. A.; Ambrosia, V. G.; Riggan, P. J.; Sebesta, P. D., Consequences of fire on aquatic nitrate and phosphate dynamics in Yellowstone National Park. In Ecological Implications of Fire in Greater Yellowstone, 1996, Greenlee, J. M., Ed.; International Association of Wildland Fire: Fairfield, WA, 1996; pp 53-57.

(72) Riggan, P. J.; Lockwood, R. N.; Jacks, P. M.; Colver, C. G.; Weirich, F.; DeBano, L. F.; Brass, J. A. Effects of fire severity on nitrate mobilization in watersheds subject to chronic atmospheric deposition. Environ. Sci. Technol. 1994, 28 (3), 369-375.
(73) Wang, G. G.; Kemball, K. J. Effects of fire severity on early development of understory vegetation. Can. J. For. Res. 2005, 35 (2), 254-262.

(74) McGlynn, B. L.; McDonnell, J. J. Role of discrete landscape units in controlling catchment dissolved organic carbon dynamics. Water Resour. Res. 2003, 39 (4), 1090.

(75) Crittenden, J. C.; Trussell, R. R.; Hand, D. W.; Howe, K. J.; Tchobanoglous, G. Water Treatment: Principles and Design, 2nd ed.; John Wiley \& Sons, Inc.: Hoboken, NJ, 2005; p 1968.

(76) Minshall, G. W.; Brock, J. T.; Andrews, D. A.; Robinson, C. T. Water quality, substratum and biotic responses of five central Idaho (USA) streams during the first year following the Mortar Creek fire. Int. J. Wildland Fire 2001, 10 (2), 185-199.

(77) Graham, R. T.; McCaffrey, S.; Jain, T. B. Science Basis for Changing Forest Structure to Modify Wildfire Behavior and Severity; USDA Forest Service, Rocky Mountain Research Station: Fort Collins, CO, 2004; p 43. 